\title{
TECTONIC EVOLUTION OF THE BETIC CORDILLERA: AN OVERVIEW
}

\author{
Alonso-Chaves, F. M. ${ }^{1}$ Soto, J. I. ${ }^{2}$, Orozco, M. ${ }^{2}$, Kilias, A. A. ${ }^{3}$ and Tranos, M. D. ${ }^{3}$ \\ ${ }^{1}$ Dep. Geodinámica y Paleontología, Univ. de Huelva, 21071-Huelva, Spain, alonso@uhu.es, \\ 2 Institute Andaluz Ciencias de la Tierra and Departamento de Geodinámica, CSIC-Granada \\ Univ.,18002-Granada, Spain, orozco@ugr.es, jsoto@ugr.es, \\ ${ }^{3}$ Department of Geology, School of Geology, Aristotle Univ. of Thessaloniki, 54124, Thessaloniki
}

\begin{abstract}
The Betic (Southern Spain) and the Rif (Morocco) mountain chains, connected through the Gibraltar Strait, shapes a W-E elongated and arcuate Alpine orogenic belt. The Alborán Sea, in continuity to the east with the South Balearic Basin, is located in the inner part of this alpine belt. The Iberian and African continental forelands bound the region as a whole to the north and south, respectively, and to the east it is connected to the oceanic Sardine-Balearic Basin. The peculiarities of these westernmost Mediterranean chains result from: (1) its position between two large convergent plates -Africa and Europe- that have had variable directions of relative motion since the late Cretaceous; and (2) the Neogene westward migration of the orogenic hinterland and its simultaneous "back-arc"-like extension, generating the Alborán Sea basin. The complexes and large paleogeographic terrains traditionally recognized in the Betic and Rif chains belong to four pre-Neogene crustal domains: the South-Iberian and Maghrebian passive continental paleomargins (External Zones of the orogen), the Flysch Units, and the Alboran Crustal Domain composed mainly of a preMiocene metamorphosed thrust-stack (Nevado-Filabride, Alpujárride, and Malaguide complexes, from bottom to top). The boundaries between the main metamorphic complexes of the Alborán Domain are extensional detachments, which finally developed under brittle conditions and are commonly sealed by middle-to-late Miocene marine-to-continental sediments. They, nonetheless, are not the most recent structures in the Alborán Domain, because upright, E-W open folds warp the extensional detachments, and finally, high-angle normal faults and strike-slip faults, many of which are still active, offset folds and extensional detachments. The tectonic evolution of the BeticAlborán orogenic system shows close similarities with the one depicted in other arcuate-shaped, Alpine mountain ranges in the Mediterranean, such as the Hellenic Arc and the Aegean Sea. Like in the westernmost Mediterranean, a thickened (pre-Miocene) crust is bounding there a thinned, continental (?) basin. Extension is also formed here in a "back-arc" setting, being developed simultaneously with the $\mathrm{N}-\mathrm{S}$ convergence between the African and European plates.
\end{abstract}

\section{THE GIBRALTAR ARC AND THE ALBORÁN BASIN IN THE WESTERN MEDITERRANEAN}

The ENE-WSW Betic Cordillera (SE Spain) and NW-SE to W-E Rif (in Morocco) elongated chains, are connected through the Gibraltar Arc and close in the Alborán Sea corresponding thus to the westernmost Alpine mountain belt in the Mediterranean (Fig. 1). The system as a whole is bounded to the north and south by the Iberian and African continental forelands, and to the east and west by the oceanic Balearic Basin and the Atlantic Ocean (Fig. 1).

The peculiarities of this westernmost Mediterranean orogenic ensemble come from the its position between two large convergent plates -Eurasia and Africa- which have undergone variable relative movements from the Mesozoic. Plate-kinematic reconstructions suggest that this plate boundary experienced about $250 \mathrm{~km}$ of approximately $\mathrm{N}-\mathrm{S}$ convergence from mid-Oligocene to late Miocene times (9-8 Ma), followed by about $50 \mathrm{~km}$ of W-NW-directed oblique convergence (e.g. Dewey et al., 1989). During the Neogene, and in spite of his plate-convergence scenario, the Al- 


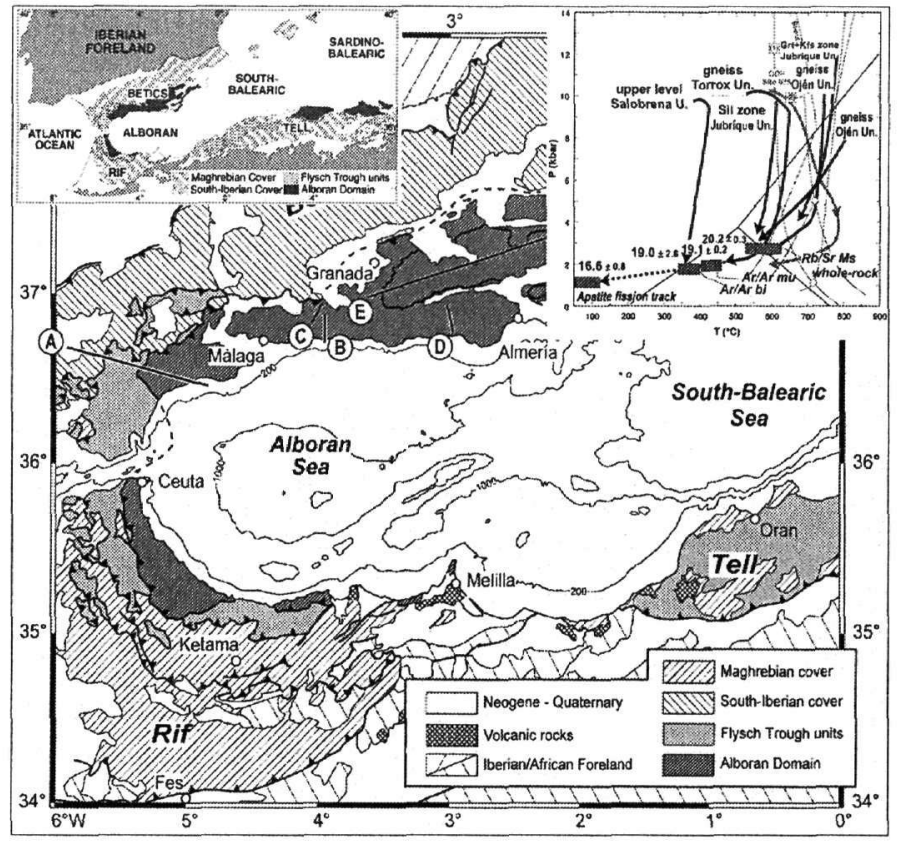

Figure 1: Tectonic map of the Betic-Rif-Alborán orogenic system in the western Mediterranean (taken from Martinez-Martinez et al., 2004). The Alpujáride/NevadoFilabride boundary is shown in the central Betics as a thick black line. Labelled cross-sections are shown in Figure 2 (sections A-C) and 3 (section D). Insets show the main crustal elements involved in the westernmost Mediterranean and P-T-t paths of several Alpujárride units of western Betic Cordillera (taken from Soto and Platt, 1999 and Comas et al., 1999).

borán Basin originated on the site of a former thickened continental crust by late-orogenic extensional processes (e.g. Dewey, 1988; Platt et al., 1998; Comas et al., 1999). The genesis of the Alborán Basin has been an extremely controversial subject and there is no general agreement about the causes of the late-orogenic extension in the Betic-Rif realm. Some authors have emphasised the role of anomalous diapirism (Weijermars, 1985) or suggested subduction similar to the western Pacific back-arc basins (e.g. Malinverno and Ryan, 1986; Morales et al., 1999). Others envisage subduction with detachment and sinking of a lithospheric slab (e.g. Zeck et al., 1992; Royden, 1993; Lonergan and White, 1997). Convective removal of a cool and dense lithophere root (Platt arıd Vissers, 1989) and asymmetric delamination or removal of the subcrustal lithophere (e.g. Garcia-Dueñas et al., 1992; Comas et al., 1999; Seber et al., 1996; Platt et al., 1998) have discussed as alternative responsible for the extensional origin of the Alborán Basin.

The large paleogeographic elements forming the Betic and Rif cordilleras, and the Gibraltar Arc, belong to four crustal domains: the South-lberian continental margin, the Maghrebian continental margin, the Flysch Trough, and the Alborán Crustal Domain (Fig. 1):

- The units of the South-Iberian and Maghrebian Domains (External Betic Zones from $\mathrm{N}$ to $\mathrm{S}$ are: Prebetic and Subbetic) correspond to the Mesozoic thinned continental margins of the Iberian and African plates, respectively.

- The Flysch Trough Domain is made up of a Complex of allochtonous units. The basement of this domain was probably an attenuated continental (oceanic?) lithosphere.

- The Alborán Crustal Domain (Internal Betic-Rif Zones) is composed of a polyphase thrust stack that includes three metamorphic nappe complexes, named (in ascending order) the NevadoFilabride, the Alpujarride, and the Malaguide complexes. Late Cretaceous and Palaeogene convergence caused substantial crustal thickening in this Domain, and generated high-pressure lowtemperature metamorphism in the lowermost complexes.

The Gibraltar Arc resulted from a westward-directed Neogene collision between the abovementioned crustal domains. Structural data evidence that in the late Oligocene the Alborán Crustal Domain thrust outward onto the South-Iberian and Maghrebian continental margins, and the dominant westward propagation of thrusting from the latest Oligocene and early Miocene led to the progression of an arcuate peripheral thrust belt (the Gibraltar Arc) (see Platt et al., 2003). Thrust directions vary from northwest in the Betic Cordillera to west in the Gibraltar region (Balanyá and Garcia-Dueñas, 1987) and to west-southwest and south in the Rif (Platt et al., 2003). Note worthily, thrusting and shortening in the peripheral belt (the External Zones of the Betic and Rif chains) were contemporaneous with extension and crustal thinning within the arc, in the Alboran Domain itself. Progression of the arcuate mountain front and extension in its inner part continued during the late Burdigalian and middle Miocene. 
Miocene extensional detachment systems and fault-bounded sedimentary basins of Miocene age are superimposed upon the continental collision structures of the Alborán Crustal Domain. The crustal thinning over much of the region, both on- and offshore, is likely to be the result of this extension. Presently, the Internal Zones of the Betic and Rif mountain chains represent the disrupted and extended fragments of the former pre-Miocene orogen, and continue below the sea floor, forming mostly the Alborán Sea basement. Results from metamorphic rocks of the Alborán Sea basement sampled by ODP-Leg 161 show that crustal extension was accompanied by heating under relatively low-pressure conditions, during the early Miocene, suggesting that extension was probably triggered by removal of the mantle lithosphere root of the former orogen (Platt et al., 1998; Soto and Platt, 1999).

The Internal Zones of the Betic Cordillera, from the western to the eastern Betics, contain numerous intra-mountain depressions and corridors filled up of Neogene to Quaternary, marine to continental sedimentary sequences. These depressions are currently known as the "Betic Neogene Basins". The basement of most of these basins corresponds to the Alpujárride and/or NevadoFilabride metamorphic complexes of the Alborán Domain. Miocene marine sediments cropping-out in the Betic Neogene Basins are similar to those that fill the Alborán Sea Basin (e.g. Comas et al., 1992).

Extensional structures recognized in the Alborán Sea basin and in the Betic Neogene Basins connected to large-scale extensional detachments known in the Betic and Rif basement units. Several extensional episodes are distinguished using the geometrical relationships between the extensional faults and the Neogene sedimentary units, namely: a $\mathrm{N}$-directed asymmetric extension of Burdigalian-Langhian age $(\approx 17-15 \mathrm{Ma})$ and a WSW-directed extension of Serravallian-early Tortonian age ( $\approx 14-10 \mathrm{Ma})$ (e.g. Garcia-Dueñas et al., 1992; Crespo-Blanc et al., 1994; Balanyá et al., 1997; Martínez-Martínez et al., 2002, 2004).

Onshore and offshore data indicate that the main rifting ceased by the latest Tortonian. After that, during the Plio-Pleistocene, contractive tectonics disjointed the Alborán Basin into sub-basins, separated by emerged or submarine highs, and E-W and WSW-ENE large folds were developed (Comas et al., 1992; Martínez-Martínez et al., 2002). Plio-Pleistocene tectonics was largely responsible for the present-day sea-floor physiography, location of the coastal line, and the topography of the area, with mountain ranges, which have locally, more than $3 \mathrm{~km}$ high peaks (e.g. Sierra Nevada and Sierra de los Filabres).

The objectives of this review paper are to summarize the structural evidence supporting the Miocene extensional collapse of the Betic orogen, as the northern branch of the Gibraltar Arc, which represents another example in the westernmost Mediterranean on how late-orogenic extension is a feasible process to overcome plate-convergence boundary conditions.

\section{ARCHITECTURE OF THE ALBORÁN DOMAIN IN THE BETIC CORDILLERA}

As we have mentioned previously, the Alborán Domain consists of a large number of stacked thrust sheets grouped into three nappe complexes: the Nevado-Filabride, the Alpujarride and the Malaguide complexes, in ascending order. Stacking occurred during the pre-Miocene in a more easterly position, probably when the Alborán Domain was a segment of the continuous Alpine orogenic belt (e.g. Malinverno and Ryan, 1986; Dewey et al., 1989).

\subsection{The Malaguide Complex}

The Malaguide rocks, ranging in age from Silurian to Oligocene, have not undergone significant Alpine metamorphism, although the Silurian series preserve Variscan orogenic features showing very low metamorphic grade (e.g. Chalouan and Michard, 1990). The exposures of this complex are largely limited to the western Betics north and east of Málaga and to a thin strip situated along the external-internal Zone boundary.

The Malaguide Complex comprises a lithologic sequence where the following constituents can be distinguished, a) in the lower part, phyllites and metagreywackes with some limestone and metaconglomerate levels to which an Ordovician-Silurian age is attributed; b) gray slates and conglomerates, mixed with which are limestones, chert and radiolarite rock layers; this lithologic ensemble is dated as Devonian-Early Carboniferous. Overlying these rocks scattered outcrops of a 
polygenic conglomerate may locally be found; c) Permo-Triassic red beds formation with conglomerates, sandstones, and lutites; and d) a condensed, carbonate sequence, where terms from Triassic to Eocene can be found.

\subsection{The Alpujárride Complex}

Rocks belonging to the Alpujárride Complex are exposed along more than $400 \mathrm{~km}$ from the western part of the Málaga province in the west to the Cartagena region in the east. The lithostratigraphic sequence of this complex comprises the following formations, from bottom to top: a mica schist formation, which locally includes gneisses and migmatites at its base; the grey to bluish-grey fine-grained schist or phyllite formation; and the carbonate formation. The carbonate formation has been dated as Middle and Late Triassic (e.g. Delgado et al., 1981); the grey fine-grained schist and phyllites, which occasionally include calc-schists in transition with the carbonates, are generally attributed to the Permo-Trias. Below the phyllites is the mica schist formation of assumed PrePermian age. The higher part of this formation comprises brown-coloured metapelites and metaquartzites. Underlying these brown metaquartzites a monotonous sequence of black mica schist crops out.

A variable number of tectonic units, differing from one traverse to another, crop out within the Alpujárride Complex (Fig. 2). Much of the Alpujárride Complex shows plurifacial Alpine metamorphism with a first HP/LT event followed by isothermal decompression inducing metamorphism of intermediate to low pressure (Goffé et al., 1989; Tubia et al., 1992; Garcia-Casco y Torres-Roldán, 1996; Azañón et al., 1997; Balanyá et al., 1997). In each Alpujárride tectonic unit the metamorphic grade increases downward in the sequence. Moreover, the upper units show a higher grade than the lower ones (Azañon et al., 1998), and frequently the metamorphic zones show condensated isogrades (Loomis, 1972; Balanyá et al., 1997).

In the western Betics a number of large Iherzolite bodies, collectively referred to as the Ronda peridotites, appear at the bottom of the metamorphic sequence of the hithermost Alpujárride unit. Upper amphibolite to granulite facies metamorphism at pressures up to about $10 \mathrm{kbar}$ is reached in the Alpujarride rocks in the vivinity of the peridotite massifs. In the same western area beneath the Ronda peridotites a relict eclogitic assemblage has been reported (Tubia and Gil Ibarguchi, 1991) suggesting pressures of the order of $15 \mathrm{kbar}$. In low-grade pelitic rocks of the Alpujárride, HP-LT carpholite-bearing relict assemblages have also been referred (Goffé et al., 1989; Azañón et al., 1998). All this is consistent with the existence of a crustal thickening event during which burial at 35 to $50 \mathrm{~km}$ depth was reached.

The timing of the crustal thickening event in the Betic-Rif orogen of southern Spain and northern Morocco is not well constrained. Estimates for the onset of the contractional deformation range from early Cretaceous to early Miocene (Platt et al., 1998), but new Ar-Ar dating from low-grade rocks of the Alpujarride Complex yield ages close to $50 \mathrm{Ma}$ which have been interpreted (Platt et al., in review) as the timing of the main contractional event and associated HP metamorphism in the Alpujárride Complex.

Published P-T paths for the Alpujárride metamorphic rocks consistently point to the existence of a rapid near-isothermal decompression (e.g. Garcia-Casco and Torres-Roldán, 1996; Balanyá et al., 1997; Azañon et al., 1998) following the first, clockwise segment of the paths, which is usually associated with the early crustal-thickening event (Goffé et al., 1989; Tubia and Gil Ibarguchi, 1991). The decompression segment of the P-T paths is associated with pervasive zrustal extension

and, according with some authors (García-Casco and Torres-Roldán, 1996; Orozco et al., 1998) bears a direct relation to the development of the $\mathrm{S} 2(=\mathrm{Sc})$ foliation and to the formation of large recumbent folds (Orozco et al., 1998; Orozco and Alonso-Chaves, 2002). These folds (Fig. 2) deform the $\mathrm{S} 1(=\mathrm{Sp}$ ) foliation and have developed a flat-lying (axial-plane) crenulation cleavage $(\mathrm{Sc})$. In phyllite and upper fine-grained mica schists $\mathrm{Sc}$ is a crenulation cleavage marked by small crystals of phengite and chlorite. In the lower part of the chloritoid schists, syn- and post-Sc andalusite has also been observed (Azañón et al., 1998). In the high-grade schists Sc, marked mainly by biotite and occasionally sillimanite, is so strong that the main foliation is a composite fabric formed by transposition of $\mathrm{Sp}$. This was followed by static crystallization of andalusite, plagioclase, and Kfeldspar porphyroblasts (Soto and Platt, 1999). 
Taking all this into account and the relationships between the folds and the extensional structures developed during the early Miocene, the formation of these recumbent folds has been interpreted to be the result of such early Miocene extensional event (Orozco et al., 1998; Orozco and Alonso-Chaves, 2002). This conclusion is supported by early Miocene $\mathrm{U}-\mathrm{Pb}$ ages on zircons from various localities across the Alborán Domain (Platt and Whitehouse, 1999) and Ar-Ar ages (19-22 Ma) on hornblende and white mica (Zeck et al., 1992; Monié et al., 1994). Moreover, fission track analysis of apatite and zircon indicate cooling to near surface conditions at around 16-18 Ma (Sosson et al., 1998; Platt et al., in review). The radiometric data imply very high rates of cooling and exhumation, which supports the interpretation that exhumation was accomplished primarily by tectonic denudation rather than erosion (Platt et al., 1998).

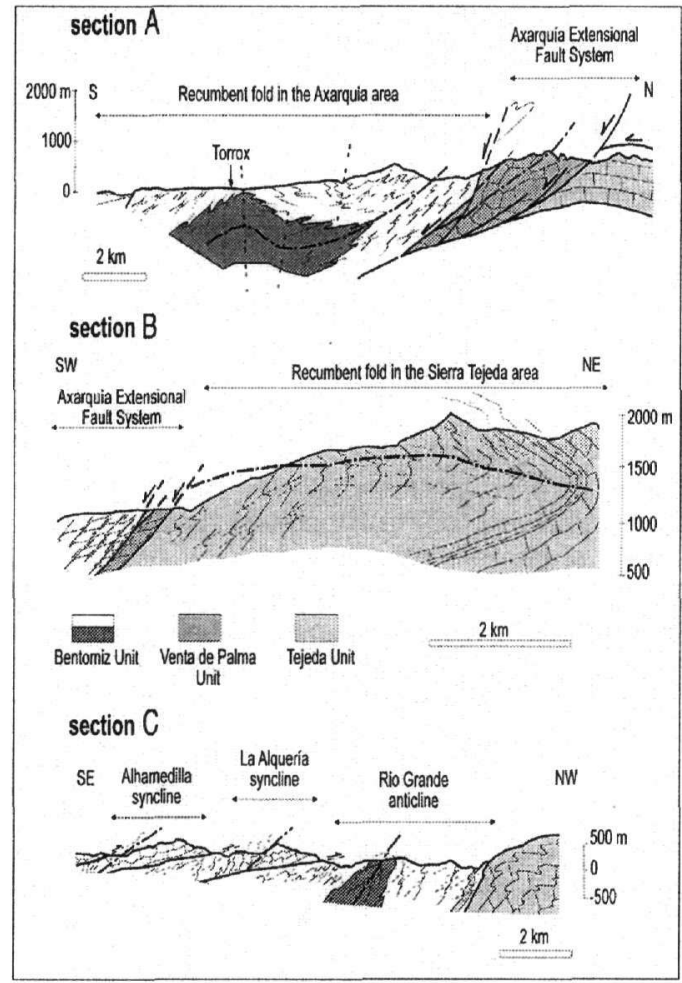

Figure 2: Large recumbent folds in the Alpujarride Complex. Section A: eastern Axarquia region (central Betics) with kynite - sillimanite gneisses at the fold core (Orozco and Alonso-Chaves, 2002). Section B: recumbent fold and the Axarquia extensional fault system, SW Sierra Tejeda (AlonsoChaves, 1995). Section C: Rio Grande anticline folds, eastern Alpujarras region (Orozco et al., 1998). See location in Figure 1.

\subsection{The Nevado-Filabride Complex}

The Nevado-Filabride rocks, ranging in age from Palaeozoic to Cretaceous, show plurifacial Alpine metamorphism with an early high pressure/low temperature (HP/LT) metamorphism, followed by high-greenschist facies in the two lower tectonic units and almandineamphibolite facies in the uppermost one (Gómez-Pugnaire and Fernández Soler, 1987; Bakker et al., 1989; Soto, 1991; Puga et al., 2002). The exhumed crustal section of the Nevado-Filabride complex consists of three major tectonic units (Ragua, Calar-Alto, and Bédar-Macael units, in ascending order; Fig. 3) separated by two ductile shear zones subparallel to both the main foliation and the lithological contacts (e.g. Garcia-Dueñas et al., 1988; Martínez-Martínez et al., 2002). The Ragua unit consists largely of low-grade, albite-rich, graphite Palaeozoic mica-schist with numerous metapsammite and quartzite rocks interlayered at top. The Calar Alto unit is formed by a sequence of chloritoid-rich, graphite-rich Palaeozoic micaschist, light-coloured Permo-Triassic schist, and Triassic marble, metamorphosed under upper greenschist facies conditions. The Bédar-Macael unit consists of a more variegated sequence of rocks including staurolite graphite mica-schist, tourmaline gneiss, light-coloured schist, serpentinite, amphibolite, and marble, metamorphosed under amphibolite facies conditions. Thermo barometric data indicate that the upper unit reached peak thermal conditions of $550^{\circ} \mathrm{C}$ and over $12 \mathrm{kbar}$ followed by a quasi-isothermal decompression (Bakker et al., 1989; Soto, 1991). The Calar-Alto unit exhibits a similar P-T path but under lower temperature conditions $\left(450^{\circ} \mathrm{C}\right)$. The metamorphic history of the Ragua unit is not well constrained, although it was metamorphosed under greenschist and albite-epidote amphibolite metamorphic conditions $\left(<450^{\circ} \mathrm{C}\right)$ and is assumed to have lower pressure conditions than the other two overlying units (de Jong, 1991; Puga et al., 2002). 


\section{MIOCENE EXTENSIONAL TECTONICS IN THE ALBORÁN DOMAIN}

The Neogene westward migration of the Gibraltar thrust was largely responsible for the collision between the Alborán Domain and the South-Iberian and Maghrebian paleomargins after the partial obliteration of the Flysch Trough Domain. In this Neogene collisional process, the rocks of both the Flysch Trough Domain and the South-Iberian and Maghrebian Domains (External Zones) were extremely shortened by thin-skinned thrusting and folding, while at the same time the Alborán Domain underwent considerable thinning with the development of extensional detachments and associated low-angle normal faults. Three major extensional detachment systems have been recognized in the Betic Cordillera, and henceforth we describe their major structures downwards in the section of the Alborán Domain.

\subsection{The Malaguide/Alpujárride extensional detachment}

The boundary between the Malaguide Complex and the underlying Alpujárride Complex is a tectonic contact of extensional nature (Garcia-Dueñas et al., 1992; Alonso-Chaves et al., 1993; Lonergan and Platt, 1995). Arguments used to recognise the extensional character of the contact include the following ones: wherever this contact is exposed, non-metamorphic (or very low-grade) Malaguide rocks are directly overlying low- to medium-grade Alpujárride metamorphic rocks. Significant pressure differences are also likely across the contact. Important lithologic omissions are also associated to this contact; in fact, the Malaguide rock sheet is tectonically lying over different Alpujárride lithologic formations or it can even be tectonically superposed over different tectonic units of the Alpujárride Complex (Orozco et al., 1998). Hence, taking into account structures indicative of direction and sense of shear, the tectonic contact appears to cut down through the Alpujarride Complex in the direction of motion (toward the $E$ in Eastern Betics and to the W-SW in the western Betics). This is certainly consistent with its extensional character.

\subsection{The Contraviesa normal fault system (intra-Alpujárride extensional detachment system)}

In the Alpujarras region, south of Sierra Nevada, Crespo-Blanc et al. (1994) carried out a revision of the boundaries between Alpujarride units in order to determine the geometry and kinematics of the tectonic contacts. The study of fault-rock bands and shear sense criteria together with the evaluation of unit and sequence omissions showed that many of the contacts formerly considered as thrusts are, in fact, low-angle normal faults developed under brittle conditions. Kinematic criteria on fault rocks clearly indicate a top-to-NNW movement. Many of the low-angle normal faults, which make up the "Contraviesa normal fault system" (Crespo-Blanc et al., 1994), have listric geometry. In the footwall of the lowermost fault plane (basal detachment) the overturned Triassic carbonates of the Lujar unit (the lowermost Alpujárride unit in the region) crop out (Orozco et al., in press). In the hanging wall of the highest low-angle normal fault observed in the region, scattered outcrops of detritic rocks of the Malaguide Complex are preserved. Therefore the "Contraviesa normal fault system", between the floor detachment and the highest low-angle normal fault along the boundary between the Malaguide and Alpujárride complexes, strongly thinned the previously much thicker, sequences of both complexes.

As pointed out in foregoing paragraphs, a common origin for the large recumbent folds of the Alpujárride Complex (Fig. 2) and the low-angle normal faults has been suggested (Orozco et al., 1998; Orozco et al., in press) taking into account the close association between north- to northwestfacing folds ant top-to-the-north low-angle normal faults of the Contraviesa fault system, the similarity in orientation of the stretching lineation associated to the folds and the slickenside direction of the faults (Crespo-Blanc et al., 1994; Orozco et al., 1998) or the fact that the recumbent folds refold extensional faults and ductile shear zones (Platt et al., in review).

The Contraviesa fault system was dated as Langhian (Mayoral et al., 1994) on the basis of microfaunal determinations of a sequence that overlies the Alpujarride and Malaguide units, south of Sierra Nevada. This is also consistent with recent Ar-Ar and fission track data from the region (Platt et al., in review), according to which the age of the main phase of late orogenic extension and exhumation would be between 19 and $23 \mathrm{Ma}$. 


\subsection{The Mecina and Filabres extensional systems (the Alpujárride/Nevado-Filabride boundary)}

The Alpujárride/Nevado-Filabride boundary, traditionally considered to be a thrust, has been interpreted as one of these extensional detachments on the basis of numerous evidence including: (1) The detachment staircase geometry showing flats and ramps cutting across and down toward the west through the thrust stack (Garcia-Dueñas and Martínez-Martínez, 1988). (2) The westward sense of hanging wall displacement. (3) The extensional geometry of the detachment-hanging wall. It is composed of tilted blocks bounded by listric normal faults coalescing on the detachment and highly extended riders (Martinez-Martinez et al., 2002). (4) The locally estimated high-values of extension for this contact, with a finite horizontal extension of $109-116 \mathrm{~km}$ (corresponding to a stretching factor, $\beta$ of around 3.5-3.9) (Martínez-Martinez et al., 2002). (5) The nature of fault rocks associated with the detachment. Beneath it there are mylonites with platy foliation and penetrative stretching lineation (Platt et al., 1983). The sense of shear deduced from the lineation orientation together with kinematic indicators are broadly consistent with a top-to-the-west sense of shear. Brittle deformation produced cataclasites, fault gouges, and tectonic breccias at the Alpujarride/Nevado-Filabride contact and postdate the mylonitic deformation. This brittle deformation exhibits a sense of shear similar to that of the earlier ductile deformation (Garcia Dueñas et al., 1988; Galindo-Zaldivar et al., 1989). (6) The existence of asymmetric footwall unroofing across the system. Cooling ages to near-surface temperatures in the footwall become younger in the direction of hanging wall motion, from $12 \mathrm{Ma}$ in the eastern Sierra de los Filabres to $9 \mathrm{Ma}$ in the western Sierra Nevada (Johnson et al., 1997). On the other hand, available Ar-Ar cooling ages from the upper plate are systematically older (19-24 Ma) than the corresponding ones from the lower plate (16-17 Ma) (Monié et al., 1991).'

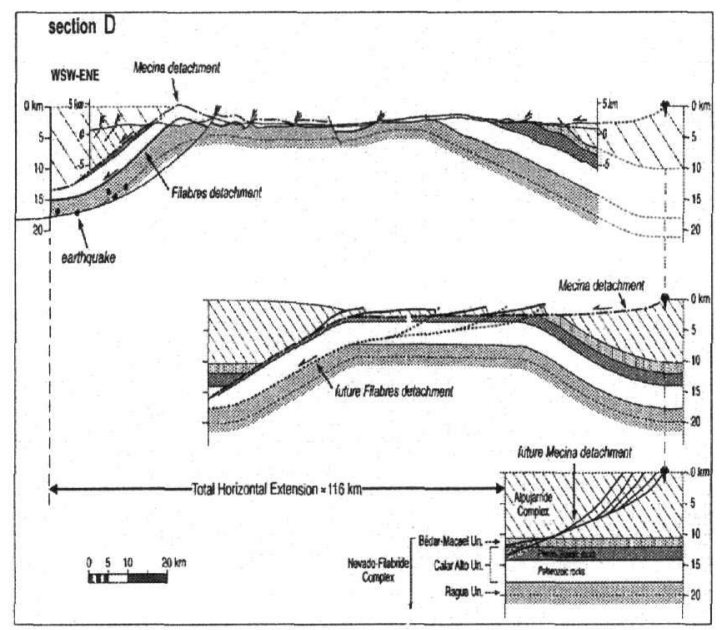

Figure 3: Structural cross-section along the Sierra Nevada elongated dome (taken from MartinezMartínez et al., 2002), parallel to the main direction of extension, showing the general structure of the Filabres and Mecina extensional detachment systems (associated to the Alpujárride / Nevado-Filabride contact). Location in Figure 1.

Two sequentially developed WSWdirected, regional-scale extensional detachments associated with low-angle normal faults caused the Miocene extension and consequent exhumation of the NevadoFilabride section in the hinterland of the Betics from a depth of 20-km (MartínezMartínez et al., 2002) (Fig. 3). They were initially shallow dipping faults (probably <

$27^{\circ}-30^{\circ}$ ), active during the Middle and Late Miocene (Martinez-Martinez et al., 2002). The Mecina low-angle normal shear zone defines the western margin of the Sierra Nevada elongated dome and consists of a mylonite zone (100-200 m thick) overprinted by a late-stage brittle detachment fault (Platt et al., 1983; Galindo-Zaldivar et al., 1989). The Filabres detachment is a later brittle-ductile, low-angle normal fault that extended the footwall of the Mecina detachment. Deformation along these two extensional systems resulted in exhumation of the Nevado-Filabride nappes from beneath the overlying Alpujarride nappes.

These extensional detachments are warped by large-scale E-W open folds, particularly east of the Granada basin, shaping an elongated domal structure that determines the present physiography of the central Betics characterized by a basin and range morphology with anticlines occupying the ranges and synclines in the basins. Two en echelon second-order domes can be recognized in central Betics mostly coinciding with the two major mountain ranges of the region, which define a whole ratio between the longitudinal and transverse fold wavelength of 1.5 to 3 . Doming here was 
caused by the interference of two orthogonal sets of Miocene-Pliocene, large-scale open folds (trending roughly E-W and N-S) (Martinez-Martinez et al., 2002, 2004). The elongated domes are laterally bounded by strike-slip faults striking subparallel to the direction of extension (ENE-WSW), which laterally adjoin highly extended domains to less extended blocks. Finally, high-angle normal faults and strike-slip faults, many of which are still active offset folds and extensional detachments.

\section{CONCLUDING REMARKS}

The Alboran Domain in the inner part of the Gibraltar Arc, westernmost end of the Alpine Mediterranean Belt, is a block of thinned continental crust, which is the last result of a complex history that involves large-scale crustal thinning during the Miocene. The previously thickened continental crust, formed probably as a result of convergent movements between the African and European plates, underwent stretching and thinning which seem to have closely followed crustal thickening. Crustal thinning in the early Miocene results in the subsidence of much of the region below sea level developing the Alborán basin (Comas et al., 1999). Therefore, the history of the Alborán basin shows clear similarities with those ones of other Mediterranean basins, e.g. the Aegean Basin, which also developed by syn- to late-orogenic extension on the site of a former mountain belt.

Taking into account the aforementioned description of the characteristic elements and timing of the Tertiary late-orogenic extension in the Betic Cordillera, it can be established that it occurred concomitantly with the westward migration of the Gibraltar thrust. Extensional denudation of the Alborán Domain was driven by low-angle faulting and extensional detachments, which migrated downward during the Miocene in the metamorphic nappe pile of the Alborán Domain. Major extensional detachments correspond finally with the boundaries between the three major metamorphic complexes in the Betic Cordillera. Extension direction varies also in the Alborán Domain pile, changing alternatively from $\mathrm{W}$ - and E-directed direction along the Malaguide/Alpujárride boundary (early to middle? Miocene); $\mathrm{N}$-directed extension along the low-angle normal faults associated to the Contraviesa extensional detachment system (middle Miocene), affecting mainly the metamorphic units of Alpujárride Complex, and finally WSW-directed extension along the Mecina and Filabres extensional detachments (middle to late Miocene) associated to the Alpujárride/NevadoFilabride boundary.

The tectonic evolution of the Betic-Alborán orogenic system during the Miocene shows close similarities with the one depicied in other arcuate-shaped, Alpine mountain ranges in the Mediterranean, such as the Hellenic Arc and the Aegean Sea (e.g. Kilias et al., 1999). Like in the westernmost Mediterranean, a thickened (pre-Miocene) crust is bounding there a thinned, continental (?) basin. Although late-orogenic extension seems to be linked certainly in this case with a retreating subduction zone, in where the upper-plate (Eurasia) migrated southwards on top of the lower, oceanic, African plate (e.g. Dercourt et al., 1986; Royden, 1993).

\section{ACKNOWLEDGMENTS}

Research Projects BTE2003-09544-C02-01 and REN2001-3868-C03MAR of the Interministerial de Ciencia y Tecnología, Spain (CICYT) supported the research.

\section{REFERENCES}

Alonso-Chaves, F.M. 1995. Evolución tectónica de Sierra Tejeda y su relación con los procesos de engrosamiento y adelgazamiento corticales en las Cordilleras Béticas. Ph. Thesis, Univ. Granada, 265 pp.

Alonso-Chaves, F.M., Garcia-Dueñas, V., and Orozco, M., 1993. Fallas de despegue extensional miocenas en el área de Sierra Tejeda (Béticas centrales). Geogaceta (Geol. Soc. Spain), 14, 116-118.

Azañón, J. M., Crespo-Blanc, A., and Garcia-Dueñas, V., 1997. Continental collision, crustal thinning, and nappe forming during the pre-Miocene evolution of the Alpujarride Complex (Alboran Domain, Betics). J. Struct. Geol., 19, 1055-1071.

Azañón, J.M., Garcia-Dueñas, V., Goffé, G., 1998. Exhumation of high-pressure metapelites and coeval crustal extension in the Alpujarride complex (Betic Cordillera). Tectonophysics, 285, 231-252. 
Bakker, H. E., De Jong, K., Helmers, H., and Bierman, C., 1989, The geodynamic evolution of the Internal Zone of the Betic Cordilleras (southeast Spain): A model based on structural analysis and geothermobarometry. J. metamorphic Geol., 7, 359-381.

Balanyá, J.C., and García-Dueñas, V., 1987, Les directions structurales dans le Domaine d'Alborán de part et d'autre du Détroit de Gibraltar. C. R. Acad. Sc. Paris, 304, 929-933.

Balanyá, J.C., García-Dueñas, V., and Azañón, J.M., 1997, Alternating contractional and extensional events in the Alpujarride nappes of the Alborán Domain (Betics, Gibraltar Arc). Tectonics, 16, 226-238.

Chalouan, A., and A. Michard, 1990. The Ghomarides nappes, Rif coastal range, Morocco: A variscan chip in the Alpine belt. Tectonics, 9, 1565-1583.

Comas, M.C., Garcia-Dueñas, V., and Jurado, M.J., 1992, Neogene Tectonic Evolution of the Alboran Sea from MSC data. Geo-Marine Lett., 12, 157-164.

Comas, M.C., Platt, J.P., Soto, J.I., and Watts, A.B., 1999, The origin and tectonic history of the Alboran Basin: Insights from Leg 161 results. In: Proceedings ODP, Scientific Results, Zahn, Z., Comas, M.C., and Klaus, A., eds., Ocean Drilling Program, College Station, TX., p. 555-580.

Crespo-Blanc, A., M. Orozco, and V. Garcia-Dueñas, 1994, Extension versus compression during the Miocene tectonic evolution of the Betic chain. Late folding of normal fault systems. Tectonics, 13, 78-88.

de Jong, K., 1991. Tectono-metamorphic studies and radiometric dating in the Betic Cordilleras (SE Spain): with implications of extension and compression in the western Mediterranean area. Ph.D. Thesis Vrije Universiteit, Amsterdam.

Delgado, F., Estévez, A., Martín, J.M., and Martín-Algarra, A., 1981. Observaciones sobre la estratigrafia de la formación carbonatada de los mantos Alpujárrides (Cordilleras Béticas). Estud. Geol., 37, 45-57.

Dercourt J. and 18 others, 1986. Geological evolution of the Tethys belt from the Atlantic to the Pamir since the Lias. Tectonophysics, 123, 241-315.

Dewey, J. F., 1988. Extensional collapse of orogens. Tectonics 7, 1123-1139.

Dewey, J.F., Helman, M.L., Turc ), E., Hutton, D.H.W., and Knott, S.D., 1989, Kinematics of the western Mediterranean. In: Alpine tectonics. Coward, M.P., Dietrich, D., and Park, R.G., eds., Geological Society [London] Special Publication, 45, 265-283.

Galindo-Zaldivar, J., Gonzalez-Lodeiro, F., and Jabaloy, A., 1989, Progressive extensional shear structures in a detachment contact in the Western Sierra Nevada (Betic Cordilleras, Spain). Geodinamica Acta (Paris), 3, 73-85.

Garcia-Casco, A., and Torres-Roldán, R.L., 1996. Disequilibrium induced by fast decompression in St-Bt-GrtKy-Sil-And Metapelites from the Betic Belt (Southern Spain). J. Petrol., 37, 1207-1239.

Garcia-Dueñas, V., and Martinez-Martínez, J.M., 1988. Sobre el adelgazamiento Mioceno del Dominio Cortical de Alborán. El despegue extensional de Filabres. Geogaceta (Geol. Soc. Spain), 5, 53-55,

Garcia-Dueñas, V., Martinez-Martínez, J.M., Orozco, M., and Soto, J.I., 1988, Plis-nappes, cisaillements syn- à post-metamorphiques et cisaillements ductiles-fragiles en distension dans les Nevado-Filabrides (Cordillères Bétiques, Espagne). C. R. Acad. Sc. Paris, 307, 1389-1395.

Garcia-Dueñas, V., Balanyá, J.C., and Martínez-Martínez, J.M., 1992, Miocene extensional detachments in the outcropping basement of the northern Alboran basin (Betics) and their tectonic implications. Geo-Marine Lett., 12, 88-95.

Goffé, B., Michard, A., García-Dueñas, V., González-Lodeiro, F., Monié, P., Campos, J., Galindo-Zaldivar, J., Jabaloy, A., Martínez-Martínez, J.M., and Simancas, F.,1989, First evidence of high-pressure, lowtemperature metamorphism in the Alpujarride nappes, Betic Cordillera (SE Spain). Eur. J. Mineral., 1, 139142.

Gómez-Pugnaire, M.T., and Fernández-Soler, J.M., 1987. High-pressure metamorphism in metabasites from the Betic Cordilleras (SE Spain) and its evolution during the Alpine orogeny. Contrib. Mineral. Petrol., 95, 231-244.

Johnson, C., Harbury, N., and Hurford, A.J., 1997, The role of extension in the Miocene denudation of the Nevado-Filábride Complex, Betic Cordillera (SE Spain). Tectonics, 16, 189-204.

Kilias, A., Falalakis, G., and Mountrakis, D., 1999. Cretaceous-Tertiary structures and kinematics of the Serbomacedonian metamorphic rocks and their relation to the exhumation of the Hellenic Hinterland (Macedonia, Greece). Int. J. Earth Sc., 88, 513-531.

Lonergan, L., and Platt, J.P., 1995. The Malaguide-Alpujarride boundary: A major extensional contact in the Internal Zone of the eastern Betic Cordillera, SE Spain. J. Struct. Geol., 17, 1655-1671.

Lonergan, L., and White, N., 1997, Origin of the Betic-Rif mountain belt. Tectonics, 16, 504-522.

Loomis, T., 1972. Contact metamorphism of pelitic rocks by the Ronda ultramafic intrusion, southern Spain. Geol. Soc. Amer. Bull., 83, 2449-2474.

Malinverno, A., and Ryan, W.F.B., 1986, Extension in the Tyrrhenian Sea and shortening in the Apennines as result of arc migration driven by sinking of the lithosphere. Tectonics, 5, 227-245. 
Martinez-Martínez, J.M., Soto, J.I., and Balanyá, J.C., 2002, Orthogonal folding of extensional detachments: structure and origin of the Sierra Nevada elonagted dome (Betics, SE Spain). Tectonics, 21, 3-1 - 3-22.

Martínez-Martínez, J.M., Soto, J.I., and Balanyá, J.C., 2004, Elongated domes in extended orogens: A mode of mountain uplift in the Betics (SE Spain). In: Gneiss domes in orogeny, Whitney, D.L, Teyssier, C., and Siddoway, C.S., eds., Geological Society of America, Special Paper, 380, Boulder, Colorado, in press.

Mayoral, E., Crespo-Blanc, A., Daz, M.G., Benot, C., and Orozco, M., 1994. Rifting miocène du Domaine d'Alboran: datations de sédiments discordants sur les unités alpujarrides en extension (Sud de la Sierra Nevada, Chaîne Bétique). C. R. Acad. Sc. Paris, 319, 581-588.

Monié, P., Galindo-Zaldivar, J., González-Lodeiro, F., Goffé, B., and Jabaloy, A., $1991,{ }^{40} \mathrm{Ar}{ }^{39} \mathrm{Ar}$ geochronology of Alpine tectonism in the Betic Cordilleras (southern Spain). J. Geol. Soc. London, 148, 289-297.

Monié, P., Torres-Roldán, R.L., and Garcia-Casco, A., 1994. Cooling and exhumation of the Western Betic Cordilleras, ${ }^{40} \mathrm{Ar} /{ }^{39} \mathrm{Ar}$ thermochronological constraints on a collapsed terrane. Tectonophyscis, 238, 353-379.

Morales, J., Serrano, I., Jabaloy, A., Galindo-Zaldivar, J., Zhao, D., Torcal, F., Vidal, F., and González-Lodeiro, F., 1999. Active continental subduction beneath the Betic Cordillera and Alboran Sea. Geology, 27, 87358738.

Orozco, M., and Alonso-Chaves, F.M., 2002. Estructuras de colapso extensional en el Dominio de Alborán. Región de La Axarquía-Sierra Tejeda (provincias de Málaga y Granada). ISBN: 84-607-5712-9. Granada, $124 \mathrm{p}$.

Orozco, M., Alonso-Chaves, F.M., and Nieto, F., 1998. Development of large north-facing folds and their relation to crustal extension in the Alborán domain (Alpujarras region, Betic Cordilleras, Spain). Tectonophysics, 298, 271-295.

Orozco, M., Álvarez-Valero, A.M., Alonso-Chaves, F.M., and Platt, J.P., 2004. Internal structure of a collapsed terrain. The Lújar syncline and its significance for the fold- and sheet-structure of the Alborán Domain (Betic Cordilleras, Spain). Tectonop hysics, in press.

Platt, J.P., and Vissers, R.L.M., 1989, Extensional collapse of thickened continental lithosphere: a working hypothesis for the Alboran Sea and Gibraltar Arc. Geology, 17, 540-543.

Platt, J.P., and Whitehouse, M.J., 1999. Early Miocene high-temperature metamorphism and rapid exhumation in the Betic Cordillera (Spain): evidence from U-Pb zircon ages. Earth Planet. Sci. Lett., 171, 591-605.

Platt, J.P., Van der Eeckhout, B., Janzen, E., Konert, G., Simon, O.J., and Weijermars, R., 1983, The structure and tectonic evolution of the Aguilón nappe, Sierra Alhamilla, Betic Cordilleras, SE Spain. J. Struct. Geol., 5 , 519-535.

Platt, J.P., Soto, J.I., Whitehouse, M.J., Hurford, A.J., and Kelley, S.P., 1998, Thermal evolution, rate of exhumation, and tectonic significance of metamorphic rocks from the floor of the Alboran extensional Basin, Western Mediterranean. Tectonics, 17, 671-689.

Platt, J.P., Allerton, S., Kirker, A., Mandeville, C., Mayfield, A., Platzman, E.S., and Rimi, A., 2003. The ultimate arc: Differential displacement, oroclinal bending, and vertical axis rotation in the External Betic-Rif arc. Tectonics, 22, 1017, doi:10.1029/2001TC001321.

Platt, J.P., Kelley, S.P., Carter, A., and Orozco, M., Timing of tectonic events in the Alpujárride Complex, Betic Cordillera, S. Spain. J. Geol. Soc. London, in review.

Puga, E., Díaz de Federico, A., and Nieto, J.M., 2002, Tectonostratigraphic subdivision and petrological characterisation of the deepest complexes of the Betic zone: A review. Geodinamica Acta (Paris), 15, 23-43.

Royden, L.H., 1993. The tectonic expression of slab pull at continental convergent boundaries. Tectonics, 12, 303-325.

Seber, D., Barazangi, M., Ibenbrahim, A., and Demnati, A. 1996. Geophysical evidence for lithospheric delamination beneath the Alboran Sea and the Rif-Betic mountains. Nature, 397, 785-790.

Sosson, M., Morillon, A.C., Bourgois, J., Féraud, G., Poupeau, G., and Saint-Marc, P., 1998. Late exhumation stages of the Alpujarride Complex (western Betic Cordilleras, Spain): new thermochronological and structural data on Los Reales and Ojén nappes. Tectonophysics, 285, 253-273.

Soto, J. I., 1991. Estructura y evolución metamórfica del complejo Nevado-Filábride en la terminación oriental de la Sierra de los Filabres (Cordilleras Béticas), Ph. Thesis, Univ. Granada, 274 pp.

Soto, J.I., and Platt, J.P., 1999, Petrological and structural evolution of high-grade metamorphic rocks from the floor of the Alboran Sea basin, Western Mediterranean. J. Petrol., 40, 21-60.

Tubia, J.M., and Gil Ibarguchi, J.I., 1991. Eclogites of the Ojén nappe: A record of subduction in the Alpujárride complex (Betic Cordilleras, southern Spain). J. Geol. Soc. London, 148:801-804.

Tubia, J.M., Cuevas, J., Navarro-Vilá, F., Alvarez, F., and Aldaya, F., 1992, Tectonic evolution of the Alpujarride Complex (Betic Cordillera, southern Spain). J. Struct. Geol., 14, 193-203.

Weijermars, R., 1985. Uplift and subsidence history of the Alboran Basin and a profile of the Alboran Diapir (WMediterranean). Geol. Mijnb., 64, 349-356.

Zeck, H.P., Monié, P., Villa, I.M., Hansen, B.T., 1992. Very high rates of cooling and uplift in the Alpine belt of the Betic Cordilleras, southern Spain. Geology, 20, 79-82. 